\title{
Field Screening of Sorghum [Sorghum bicolor (L.) Moench] Inbred Lines for Resistance to Striga [Striga hermonthica (Del.)] in East Hararghe, Ethiopia
}

\author{
Zeleke Legesse $^{1 *} \quad$ Bulti Tesso $^{2} \quad$ Taye Tadesse ${ }^{3}$ \\ 1.Fedis Agricultural Research Center P.O. Box, 904 Harar, Ethiopia \\ 2.Haramaya University, P.O.Box, 138 \\ 3.Ethiopian Institute of Agricultural research, P.O.Box, 2003, Addis Ababa
}

\begin{abstract}
Drought and the obligate Striga root parasite are two of the most important constraints to sorghum production in the northern and north eastern parts of Ethiopia. This study assessed the field reaction of selected advanced lines under Striga hermonthica infestation condition. Twenty-two sorghum genotypes with two resistant checks (Gobiye and SRN-39) and one susceptible check (Teshale) were evaluated under Striga hot spot area at Fadis Agricultural Research Center, Boko research station (Ethiopia) in the 2016 season using a $5 \times 5$ triple lattice design. During the field experiment, 11 parameters were measured among which Striga count emerged on each genotype was the indicator of resistance genotypes. Genotypes differed significantly in all measured parameters in their reactions to Striga. Genotypes 2006 MW 6044, ETSC 300003, ETSC 300081, 05 MW 6019, and ETSC 300080 showed Striga resistance in the field. Thus, these genotypes were the most promising sources of resistance to $S$. hermonthica. From field experiments, it could be suggested that genetic variability for resistance and tolerance is available in a range of genotypes, which could be used for future breeding and production in Striga infested areas.
\end{abstract}

Keywords: genotypes, germination stimulant, parasitic weed, resistant, screening techniques

DOI: $10.7176 / \mathrm{FSQM} / 105-01$

Publication date: February $28^{\text {th }} 2021$

\section{INTRODUCTION}

Sorghum [Sorghum bicolor (L.) Moench] is the fifth most important grain crop globally after maize, wheat, rice, and barley (FAO, 2015). It is the most important staple food crop for more than 500 million people in Africa, Asia and Latin America, particularly in semi-arid tropical regions where drought is the major limitation to food production (Ejeta, 2005). Under favorable conditions, sorghum has a higher yield potential than other major cereals, such as rice (Oryza sativa), wheat (Triticum spp.) and maize (Zea mays) (Reddy et al., 2012).

In Ethiopia, sorghum is the most important cereal crop, particularly in lowland areas where rainfall is unreliable and in places where crop failures are common due to recurrent drought. The crop is one of the major food cereals, like tef, wheat, maize and barley (CSA, 2015). It ranks second after maize in total production, third after wheat and maize in productivity per hectare, and after tef and maize in area cultivated. Sorghum is cultivated in almost all regions, covering a total land area of 1.86 million hectares and grown mainly in dry-lands and semi-arid areas of Ethiopia where drought and poor harvests are common. It is considered as the principal crop providing means of survival (CSA, 2016).

Currently, sorghum is produced by 4.96 million householders with production giving the potential average grain yield of 2.3 tons per-hectare (CSA, 2016). However, various biotic and a biotic factors contributed to the low productivity of sorghum. Among the biotic factors, weed, mainly Striga is the most important cause of yield loss in most regions of Ethiopia (Rebeka et al., 2014. Hussien (2006) stated that Striga species have become the most common parasitic weeds in sorghum producing areas of eastern Ethiopia. In Ethiopia, losses of $65-100 \%$ are common in heavily infested fields (Ejeta et al., 2002). Its effect depends on the crop genotype, degree of infestation, rainfall pattern, and fertility of the soil (Aly, 2007).

Striga, once introduced into the field, will remain as a serious challenge for eradication due to its ability of producing large number of seeds per plant. Striga seeds require a period of pre-treatment 'conditioning' in a moist warm environment for 2-14 days before they have the potential to germinate (Logan and Stewart, 1991). Germination occurs in response to an exogenous stimulant. In nature, the stimulant is exuded from the roots of host and some non-host plants. So far, three different types of compounds have been identified as germination stimulants for root parasitic plants; dihydroquinones, sesquiterpene lactones and Strigo-lactones (SLs) (Bouwmeester et al., 2003).

Effective, affordable, and sustainable management options are needed to enhance small-scale sorghum productivity in areas where the parasite occurs. The use of resistant cultivars is a most robust and effective approach to management parasitic weeds. Host-plant resistance in adapted, productive cultivars is a central component of integrated Striga management. The uses of resistant varieties have been promoted as the most 
affordable, effective, and environmentally sound method for the management of Striga. This has been demonstrated in multi-location field tests conducted in Ethiopia and Tanzania (Tesfaye et al., 2007). In Ethiopia there is significant genetic variation for Striga resistance in sorghum (Tokuma, 2016). Precise and reliable screening techniques are indispensable in order to select Striga resistant lines through breeding (Vasudeva, 1985). The presence of individual mechanisms conferring resistance to Striga may be examined in the laboratory, whereas complex resistance must be assessed under field conditions (Haussmann et al., 2000).

Ethiopia, so far about four varieties have been released for production in Striga infested areas of the country. However, with the diversity of sorghum growing environments and the expanding effect of Striga on sorghum production, developing additional varieties that have high yield potential and Striga resistance is one of the priorities. Therefore, the present study aimed to identify the Striga resistant/tolerant sorghum inbred lines under field conditions.

\section{MATERIALS AND METHODS}

\section{Description of the study area}

The experiment was conducted at the Fadis Agricultural Research Center (FARC) of Fadis research site in East Hararghe, Ethiopia. This area, under rain-fed conditions, was used from July 2016 to November 2016. It lies between $8^{\circ} 22^{\prime}$ and $9^{\circ} 14^{\prime}$ North latitude, and $42^{\circ} 02^{\prime}$ and $42^{\circ} 19^{\prime}$ East longitude. Fadis is located at $1700 \mathrm{~m}$ a.s.l. with a mean annual rainfall of $804 \mathrm{~mm}$; the annual minimum and maximum ambient temperature is $20-25^{\circ} \mathrm{C}$. and $30-35^{\circ} \mathrm{C}$., respectively (Samuel et al., 2013).

The seasonal temperature and total amount of rainfall in the study area were major constraints for Striga plants to emerge during 2016. In the 2016 cropping season, almost no satisfactory rain occurred during the critical growth stage (phonology) of the sorghum crop (i.e. flowering, heading, and physiological maturity stages) at which the Striga plants were expected to emerge. The crop headed in August with $56.8 \mathrm{~mm}$ of rainfall. The total rainfall during the year $(2016)$ was $(72.5 \mathrm{~mm})$, which is far less than the average rain fall of the last six (2010-2015) years (129.3mm) (Table 1), and this made the Striga plants to enter into secondary dormancy. Rainfall distribution was also erratic, particularly during the flowering and physiological maturity of the crop (Table 1). As a result, Striga emergence was few in number, causing low infestation level on the crop. Striga seeds normally require a period of pre-treatment 'conditioning' in a moist warm environment for 2-14 days before they have the potential to germinate (Logan and Stewart 1991).

Table 1: Monthly rainfall and temperature of 2010-2015 and 2016 growing seasons at Fadis

\begin{tabular}{|c|c|c|c|c|c|c|}
\hline \multirow[b]{3}{*}{ Month } & \multicolumn{3}{|c|}{ 2010-2015 Meteorological data } & \multicolumn{3}{|c|}{2016 Meteorological Data } \\
\hline & \multirow[t]{2}{*}{ Rainfall (mm) } & \multicolumn{2}{|c|}{ Temperature $\left({ }^{\circ} \mathrm{C}\right)$} & \multirow[t]{2}{*}{ Rainfall (mm) } & \multicolumn{2}{|c|}{ Temperature $\left({ }^{\circ} \mathrm{C}\right)$} \\
\hline & & Min. & Max. & & Minimum & Maximum \\
\hline January & 7.05 & 7.85 & 28.53 & 4.7 & 9.4 & 28.9 \\
\hline February & 12.83 & 8.67 & 30.10 & 0.0 & 8.6 & 31.5 \\
\hline March & 97.17 & 10.22 & 30.08 & 26.4 & 11.4 & 33.6 \\
\hline April & 114.82 & 11.57 & 28.97 & 239.5 & 12.2 & 28.5 \\
\hline May & 148.35 & 11.60 & 27.9 & 170.6 & 11.3 & 28.0 \\
\hline June & 67.79 & 9.69 & 27.71 & 94.8 & 10.6 & 27.2 \\
\hline July & 85.63 & 12.23 & 26.47 & 96.3 & 11.0 & 26.9 \\
\hline August & 129.33 & 18.481 & 26.93 & 56.8 & 10.7 & 27.3 \\
\hline September & 144.84 & 20.69 & 27.31 & 100 & 10.8 & 28.8 \\
\hline October & 72.87 & 10.41 & 28.29 & 36.3 & 10.0 & 28.9 \\
\hline November & 23.66 & 3.38 & 28.30 & 48.7 & 8.2 & 29.2 \\
\hline December & 2.03 & 0.29 & 27.91 & 9.7 & 7.9 & 29.1 \\
\hline Total & 852.04 & --- & ---- & 883.8 & --- & --- \\
\hline Average & -- & 10.14 & 26.48 & - & 10.17 & 28.99 \\
\hline
\end{tabular}

Source: Regional Meteorological Station of Fadis Agricultural Research Center, Fadis, Eastern Hararghe Zone, Oromia, Ethiopia

\section{Experimental Materials and Design}

Twenty two sorghum genotypes developed from crosses of improved sorghum genotypes with known sources of Striga resistant genes and three standard checks, 'Gobiye' and 'SNR-39' as resistant and 'Teshale' as susceptible were used for field evaluation. The genotypes were advanced from the pedigree breeding program of the National Sorghum Improvement Program at Melkassa Agricultural Research Center and selfed up to $\mathrm{F}_{6}$ stage, which were screened for resistance to Striga in Striga infested areas of Ethiopia.

The field experiment was conducted at the Fadis Research site on hot spot area for Striga hermonthica during the 2016 main cropping season. The treatments were arranged in 5 x 5 triple lattice designs. The plots size was two rows and $4.5 \mathrm{~m}$ long, with spacing of $75 \mathrm{~cm}$ between rows and $15 \mathrm{~cm}$ within rows. The distances 
between replications and between plots were $1.5 \mathrm{~m}$ and $1 \mathrm{~m}$, respectively. The seeds were manually drilled by hand into the rows, and the seedlings were thinned to $0.15 \mathrm{~m}$ distance between plants approximately 20 days after emergence.

Fertilizers were applied at rates of $100 \mathrm{kgha}^{-1}$ and $40 \mathrm{kgha}^{-1}$ DAP and Urea, respectively. The plots were weeded as frequently as needed by leaving the Striga weeds.

\section{Data collection}

Phonological and morphological data of sorghum such as; days to $50 \%$ emergence, days to $50 \%$ flowering, days to physiological, plant height $(\mathrm{cm})$.

Yield and yield components: - panicle length $(\mathrm{cm})$, stand count, above ground biomass (AGB)

$(\mathrm{kg}), 1000$ kernels weight $(\mathrm{g})$ grain yield $(\mathrm{GY})(\mathrm{kg})$ adjusted to $12 \%$ moisture level, harvest index (HI).

Striga and Striga-related data: - Striga count at heading, flowering and harvest were taken from the sorghum

plots. The Striga count data were square root transformed $(\sqrt{\boldsymbol{X}+\mathbf{0 . 5}})$, where $\mathrm{x}$ is the original value.

\section{Data analysis}

Data were analyzed using Genstat $18^{\text {th }}$ edition and treatment means were separated using the least significance difference (LSD) test at 5\% level.

\section{RESULTS AND DISCUSSION}

The analysis of variance (ANOVA) showed significant differences among the genotypes $(\mathrm{P} \leq 0.05)$ for all the traits measured. The tested genotypes showed highly significant $(\mathrm{P} \leq 0.01)$ variation on days to $50 \%$ flowering, Striga count at flowering and maturity, plant height, panicle length, days to maturity, grain yield, above ground biomass and thousand seed weight. Stand count at harvest for all genotypes was not significant, whereas harvest index showed significance difference $(\mathrm{P} \leq 0.05)$ (Table 2).

Table 2. Analysis of variance for Striga, growth and Phenological traits, and yield and yield related traits of 25 sorghum genotypes tested at Fadis in 2016/17

\begin{tabular}{|c|c|c|c|c|c|c|c|c|c|c|c|c|}
\hline & \multicolumn{12}{|c|}{ Mean squares } \\
\hline Source of variation & $\mathrm{DF}$ & FD & SCF & $\mathrm{SCH}$ & PH & PL & $\mathrm{StC}$ & DM & GY & AGB & TSW & HI \\
\hline Replications & 2 & 37.92 & 0.015 & 0.0225 & 21.37 & 2.93 & 2.8886 & 45.81 & 864839 & 9274032 & 7.84 & 89.13 \\
\hline $\begin{array}{l}\text { Blocks within } \\
\text { Replications (Adj.) }\end{array}$ & 12 & 9.91 & 0.0069 & 0.1315 & 47.97 & 4.69 & 52362600 & 15.66 & 150452 & 1095616 & 5.1 & 24.73 \\
\hline Treatments (Unadj.) & 24 & $62.49 * *$ & $0.7379^{* *}$ & $1.4428 * *$ & $754.28 * *$ & $16.19^{* *}$ & $1.529^{\mathrm{ns}}$ & $106.05 * *$ & $775216^{* *}$ & $5623234^{* *}$ & $22.4^{* *}$ & $45.77 *$ \\
\hline Intra Block Error & 36 & 11.46 & 0.0057 & 0.1055 & 46.92 & 2.4 & 1.3968 & 17.86 & 75655 & 1233966 & 5.4 & 28.9 \\
\hline RCBD Error & 48 & 11.07 & 0.006 & 0.1120 & 47.18 & 2.97 & 1.1785 & 17.31 & 94354 & 1199378 & 5.33 & 27.86 \\
\hline Total & 74 & 28.47 & 0.2436 & 0.5412 & 275.81 & 7.25 & 1.3384 & 46.86 & 335998 & 2852376 & 10.94 & 35.32 \\
\hline
\end{tabular}

** and * -significant at $\mathrm{p} \leq 0.01$ and $\mathrm{p} \leq 0.05$ probability level, respectively, $\mathrm{DF}=$ Days to flowering; $\mathrm{PH}=\mathrm{Plant}$ height; $\mathrm{DM}=$ Days to maturity; $\mathrm{SCF}=$ Striga count at flowering; $\mathrm{SCH}=$ Striga count at Harvesting; $\mathrm{PL}=\mathrm{Panicle}$ length; $\mathrm{StC}=\mathrm{Stand}$ count; $\mathrm{GY}=$ Grain yield; $\mathrm{AGB}=$ above ground biomass; $\mathrm{TSW}=$ Thousand seed weight; $\mathrm{HI}=$ Harvest Index

\section{Days to $50 \%$ flowering}

Flowering duration is one of the variety selection criteria, in particular in areas where drought and Striga are the major problems. The analysis of variance (Table 3) revealed that disparity in days to 50 percent flowering $\mathbf{( 5 0 \% D F})$ in sorghum genotypes was highly significant $(\mathrm{P} \leq 0.01)$. The overall average days to flowering was 74 days with a range of 68.3 days for the genotype ETSC 300003 to 85 days for the genotype 2006 MW 6112 . Four of the late flowered sorghum genotypes 2006 MW 6112, 2006 MW 6044, 2006 MW 6123 and 2006 MW 6185 had similarity in flowering duration.

The early flowering genotypes ETSC 300003, 05 MW 6028, 05 MW 6073, ETSC 300081, ETSC 300085, 2006 MW 6067, ETSC 300086, ETSC 300087, 05 MW 6066, ETSC 300083, ETSC 300080, 05 MW 6005 and the two resistant checks (SRN-39 and Gobiye) were not significantly different in flowering time. These early genotypes could be potential genotypes for the target environment (Fadis), provided that they are resistant to Striga and give better yield. The genotypes have different genetic background, which might be the reason for the variation in flowering duration among the tested genotypes. These results are in line with the findings of Hassan (2005) and Ayelene (2011).

\section{Plant height}

The overall mean plant height $(\mathrm{PH})$ recorded was $157.69 \mathrm{~cm}$. Greater variation in plant height ranging from 113.3 to $194 \mathrm{~cm}$ was observed (Table 3). The maximum height was measured in genotype $2006 \mathrm{MW} 6185$ which 
was the tallest $(194.0 \mathrm{~cm})$ among the 25 genotypes and produced more than $36.31 \mathrm{~cm}$ long and remained significantly taller than all the sorghum genotypes tested. From the sorghum genotypes evaluated $148 \mathrm{x}$ Framida recorded shorter height of $128.0 \mathrm{~cm}$. It was followed by genotypes $05 \mathrm{MW} 6066$, ETSC 300081, ETSC 300080, 2006 MW 6145, 2006 MW 6067, 05 MW 6028, 2006 MW 6112, ETSC 300083, and ETSC 300082, which were not significantly different from each other. These genotypes are important for areas were biomass is needed by farmers. The check variety Gobiye had the shortest mean $(113.3 \mathrm{~cm}) \mathrm{PH}$. This finding is in line with the observation of Hesse and Lenné (1999) who stated that variability in plant height among sorghum progenies was attributed to genetic differences.

\section{Days to physiological maturity}

In present study, highly significant $(\mathrm{P} \leq 0.01)$ variation in days taken to physiological maturity (DM) was observed among various sorghum genotypes (Table 3). The physiological maturity period ranged from 116 to 138 days with a mean of 127.05 days. The genotype ETSC 300082 was the earliest (118.0 days) in physiological maturity and was not significantly different from the standard check (Gobiye), other three genotypes, namely; ETSC 300083, ETSC 300081, ETSC 300087, and one of the resistant check SRN-39 were early in maturity availing 116.3, 121.0, 122.0, 122.3 and 119.7 days, respectively (Table 3). All these lines were statistically comparable to each other, i.e. no significant differences. The latest maturing sorghum genotype was 2006 MW 6044, with a mean value of 138.0 days and statistically at par with genotypes 2006 MW 6112, 2006 MW 6145 , 2006 MW 6067, 2006 MW 6185, 2006 MW 6123, 06 MW 6015 and the susceptible check (Teshale). Such types of variability in maturity have also been reported by earlier scientists. The normal maturing crops are usually considered ideal for grain yield. Delayed leaf senescence, or stay green in grain sorghum allows continued photosynthesis under drought conditions leading to normal grain filling and larger yields compared to senescent cultivars (Sami et al., 2013).

Table 3: Mean values of phenological and growth parameters of sorghum genotypes tested at Fadis in 2016 cropping season

\begin{tabular}{|c|c|c|c|c|}
\hline \multirow[t]{2}{*}{ Genotype } & \multicolumn{4}{|c|}{ Traits } \\
\hline & $\mathrm{DE}$ & FD & $\mathrm{PH}(\mathrm{cm})$ & $\mathrm{DM}$ \\
\hline 1. $2006 \mathrm{MW} 6044$ & $9^{a}$ & $82.3^{\mathrm{ab}}$ & $162.0^{\mathrm{c}-\mathrm{g}}$ & $138.0^{\mathrm{a}}$ \\
\hline 2. ETSC 300003 & $7^{\mathrm{d}}$ & $67.7^{\mathrm{h}}$ & $155.7^{\mathrm{f}-\mathrm{h}}$ & $123.3^{\mathrm{e}-\mathrm{i}}$ \\
\hline 3. 05MW6019 & $8^{\mathrm{bc}}$ & $76.3^{\mathrm{c}-\mathrm{f}}$ & $152.0^{\mathrm{gh}}$ & $126.7^{\mathrm{d}-\mathrm{g}}$ \\
\hline 4. $05 \mathrm{MW} 6073$ & $7.3^{\mathrm{cd}}$ & $69^{\text {gh }}$ & $153.3^{\mathrm{gh}}$ & $125.7^{\mathrm{d}-\mathrm{h}}$ \\
\hline 5. $2006 \mathrm{MW} 6185$ & $9^{\mathrm{a}}$ & $80^{\mathrm{a}-\mathrm{c}}$ & $194.0^{\mathrm{a}}$ & $132.3^{\mathrm{a}-\mathrm{d}}$ \\
\hline 6. ETSC 300081 & $7.3^{\mathrm{cd}}$ & $69.3^{\mathrm{gh}}$ & $171.3^{b c}$ & $122.0^{\mathrm{f}-\mathrm{j}}$ \\
\hline 7. ETSC 300086 & $7^{\mathrm{d}}$ & $71.3^{\mathrm{f}-\mathrm{h}}$ & $157 .^{7 \mathrm{e}-\mathrm{h}}$ & $125.7^{\mathrm{d}-\mathrm{h}}$ \\
\hline 8. ETSC 300080 & $8^{\mathrm{bc}}$ & $73^{e-h}$ & $169.3^{\mathrm{b}-\mathrm{d}}$ & $123.3^{\mathrm{e}-\mathrm{i}}$ \\
\hline 9. $2006 \mathrm{MW} 6145$ & $9^{a}$ & $75.3^{\mathrm{c}-\mathrm{f}}$ & $169.0^{\mathrm{b}-\mathrm{d}}$ & $135.7^{\mathrm{a}-\mathrm{c}}$ \\
\hline 10.ETSC 300087 & $7.3^{\mathrm{cd}}$ & $71.7^{\mathrm{f}-\mathrm{h}}$ & $156.7^{\mathrm{f}-\mathrm{h}}$ & $122.3^{\mathrm{f}-\mathrm{j}}$ \\
\hline 11.2006 MW 6112 & $8.6^{\mathrm{ab}}$ & $85^{\mathrm{a}}$ & $163.0^{\mathrm{b}-\mathrm{g}}$ & $136.7^{\mathrm{ab}}$ \\
\hline 12.148 X Framida & $8.6^{\mathrm{ab}}$ & $74.3^{\mathrm{d}-\mathrm{g}}$ & $128.0^{\mathrm{i}}$ & $123.3^{\mathrm{e}-\mathrm{i}}$ \\
\hline $13.05 \mathrm{MW} 6066$ & $7.6^{\mathrm{cd}}$ & $71.7^{\mathrm{f}-\mathrm{h}}$ & $173.7^{\mathrm{b}}$ & $129.3^{\mathrm{c}-\mathrm{e}}$ \\
\hline 14.06 MW 6015 & $8^{\mathrm{bc}}$ & $77.7^{\mathrm{b}-\mathrm{e}}$ & $150.3^{\mathrm{h}}$ & $131.3^{\mathrm{a}-\mathrm{d}}$ \\
\hline 15.ETSC 300085 & $7.3^{\mathrm{cd}}$ & $69.7^{\mathrm{gh}}$ & $152.0^{\mathrm{gh}}$ & $126.3^{\mathrm{d}-\mathrm{h}}$ \\
\hline 16.2006 MW 6067 & $7.6^{\mathrm{cd}}$ & $71^{\mathrm{f}-\mathrm{h}}$ & $168.7^{\mathrm{b}-\mathrm{e}}$ & $135.3^{\mathrm{a}-\mathrm{c}}$ \\
\hline $17.05 \mathrm{MW} 6005$ & $8^{\mathrm{bc}}$ & $73^{e-h}$ & $153.7^{\mathrm{gh}}$ & $128.0^{\mathrm{d}-\mathrm{f}}$ \\
\hline 18.ETSC 300083 & $7.6^{\mathrm{cd}}$ & $72.3^{\mathrm{e}-\mathrm{h}}$ & $165.7^{b-f}$ & $121.0^{\mathrm{g}-\mathrm{j}}$ \\
\hline 19.ETSC 300082 & $7.6^{\mathrm{cd}}$ & $77.7^{\mathrm{b}-\mathrm{e}}$ & $162 .^{7 \mathrm{~b}-\mathrm{g}}$ & $118.0^{\mathrm{ij}}$ \\
\hline $20.05 \mathrm{MW} 6028$ & $7.6^{\mathrm{cd}}$ & $68.3^{\mathrm{h}}$ & $163.0^{\mathrm{b}-\mathrm{g}}$ & $123.3^{\mathrm{e}-\mathrm{i}}$ \\
\hline $21.2006 \mathrm{MW} 6123$ & $8^{\mathrm{bc}}$ & $80.3^{\mathrm{a}-\mathrm{c}}$ & $153.7^{\mathrm{gh}}$ & $131.3^{\mathrm{a}-\mathrm{d}}$ \\
\hline 22.SPV-245 X 1(146 X 354)-27 xFramida-7-1 & $8^{\mathrm{bc}}$ & $75.7^{\mathrm{c}-\mathrm{f}}$ & $162 .^{3 \mathrm{c}-\mathrm{g}}$ & $130.0^{\mathrm{b}-\mathrm{e}}$ \\
\hline 23.SRN-39 & $8.7^{\mathrm{ab}}$ & $73^{\mathrm{e}-\mathrm{h}}$ & $131.7^{\mathrm{i}}$ & $119.7^{\mathrm{h}-\mathrm{j}}$ \\
\hline 24.Teshale & $9^{\mathrm{a}}$ & $79^{\mathrm{b}-\mathrm{d}}$ & $159 .^{7 \mathrm{~d}-\mathrm{h}}$ & $131.3^{\mathrm{a}-\mathrm{d}}$ \\
\hline 25.Gobiye & $7.3^{\mathrm{cd}}$ & $72.3^{\mathrm{e}-\mathrm{h}}$ & $113.3^{\mathrm{j}}$ & $116.3^{\mathrm{j}}$ \\
\hline $\operatorname{LSD}(5 \%)$ & 0.94 & 5.46 & 11.28 & 6.83 \\
\hline $\mathrm{CV}(\%)$ & 7.2 & 4.5 & 4.4 & 3.3 \\
\hline
\end{tabular}

Means with the same letters are not significantly different from each other'; $\mathrm{DE}=$ days to $50 \%$ emergence; $\mathrm{DF}=$ days to $50 \%$ flowering; $\mathrm{PH}=$ plant height; $\mathrm{DM}=$ days to maturity 


\title{
Yield and yield components \\ Panicle length
}

Analysis of variance for panicle length $(\mathrm{PL})$ showed highly significant $(\mathrm{P} \leq 0.01)$ difference among genotypes (Table 4). The overall average value for PL was $23.4 \mathrm{~cm}$, with the range between 19.67 and $29.00 \mathrm{~cm}$ (Table 4). The genotype 2006 MW 6044 had the longest $(29.0 \mathrm{~cm})$ PL followed by the genotype 2006 MW 6145 and $148 \mathrm{x}$ Framida. The shortest $(19.7 \mathrm{~cm})$ panicle was recorded in susceptible check Teshale, which was not significantly different from genotypes;05 MW 6073, ETSC 300086, ETSC 300080, 05 MW 6005, ETSC 300083, ETSC 300082, Spv-245x1(146 x 354)-27 x Framida-7-1 and one of the resistant check SRN-39. From this study, PL and the grain yield were not directly relationship in which some genotypes recorded longest PL, but did not produced highest grain yield and vice versa.

\begin{abstract}
Aboveground dry biomass (AGB)
Analysis of variance (ANOVA) showed highly significant $(\mathrm{P} \leq 0.01)$ differences in aboveground dry biomass yield among the genotypes with a mean of $5949.4 \mathrm{kgha}^{-1}$ and arrange of 3243to $10457 \mathrm{kgha}^{-1}$ (Table 6). Genotype 2006 MW 6185 had the highest (10457 kg ha-1) AGB yield, whereas the smallest $\left(3243 \mathrm{~kg} \mathrm{ha}^{-1}\right)$ was recorded for ETSC 300087) (Table 4). The genotypes 2006 MW 6185 had highest grain yield and AGB. However, the line ETSC 300087 had the lowest values of both grain yield and above ground dry biomass. This genotype supported high Striga plants and was judged as susceptible to Striga. This result confirms the findings of Ast et al. (2000) who reported that the AGB in Tiemarifing (tolerant sorghum landrace) was found to be three times greater than that of CK60-B (sensitive sorghum cultivar).
\end{abstract}

\section{Thousand Seed weight}

Grain size is an important yield component as it is directly proportional to seed yield. Thousand seed weight (TSW) was highly significantly $(\mathrm{P} \leq 0.01)$ different among the genotypes (Table 4$)$. The overall average 1000 seed weight was $24.70 \mathrm{~g}$ with a range of 29.7 to $39.33 \mathrm{~g}$. The heaviest seeds $(39.3 \mathrm{~g}$ per 1000 seed) were produced by genotype ETSC 300080 followed by 2006 MW 606, ETSC 300085, 05 MW 6073, ETSC 300086 and $05 \mathrm{MW} 6005$ which in turn showed 38.7, 38.3, 37.7, 37.7 and $36.7 \mathrm{~g}$, respectively and were not significant from the heaviest genotype. The smallest size grain was found in genotype SRN-39 $(29.7 \mathrm{~g})$ and at par with eight sorghum genotypes tested. In this study variability on TSW were observed among sorghum genotypes, which differed in their seed size and the yield recorded from them. Similar observations regarding variability in weight of grains in sorghum were also reported by Muhammad et al. (2015).

\section{Grain yield}

The variability in grain yield (GY) produced by different sorghum genotypes was found to be highly significant $(\mathrm{P} \leq 0.01)$. The mean GY value of the genotypes ranged from 1068 to $3283 \mathrm{~kg} \mathrm{ha}^{-1}$, indicating large variation among the genotypes (Table 4). This large yield variation with other important parameters among genotypes could help in the selection of superior genotypes for the area. The highest $\left(3283 \mathrm{~kg} \mathrm{ha}^{-1}\right)$ grain yield was obtained from 2006 MW 6185. In addition, four genotypes (SPV-245 X 1(146 X 354)-27 X Framida-7-1, 05 MW 6073, ETSC 300003 and 05 MW 6005) gave high yields (Table 4). These lines were statistically at par with each other and significantly better than rest of 20 sorghum genotypes.

In comparison to the Striga resistant check variety (SRN 39), two genotypes namely 2006 MW 6185 and SPV-245 X 1(146 X 354)-27 XFramida-7-1 gave higher mean GY. Twelve of the tested genotypes out yielded the standard check variety (Gobiye), indicating the possibility of obtaining better yielding varieties. However,

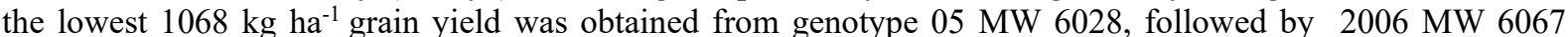
(1093 kg ha-1), 05 MW $6019\left(1287 \mathrm{~kg} \mathrm{ha}^{-1}\right)$, ETSC $300087\left(1293 \mathrm{~kg} \mathrm{ha}^{-1}\right), 06 \mathrm{MW} 6015$ (1310 kg ha-1), $05 \mathrm{MW}$ $6066\left(1445 \mathrm{~kg} \mathrm{ha}^{-1}\right)$ and $2006 \mathrm{MW} 6044\left(1560 \mathrm{~kg} \mathrm{ha}^{-1}\right)$. These genotypes were not significantly different from each other and showed poor performance. The highest range of genetic variability in grain yield of sorghum genotypes were observed similar to this study was also reported by Muhammad et al. (2015). 
Table 4: Mean values of yield, yield related for the genotypes tested at Fadis in 2016 crop season

\begin{tabular}{|c|c|c|c|c|c|c|}
\hline \multirow[b]{2}{*}{ Genotype } & \multicolumn{6}{|c|}{ Traits } \\
\hline & $\begin{array}{l}\mathrm{PL} \\
(\mathrm{cm})\end{array}$ & $\mathrm{StC}$ & $\begin{array}{l}\text { GY } \\
\left(\mathrm{kg} \mathrm{ha}^{-1}\right)\end{array}$ & $\begin{array}{l}\mathrm{AGB} \\
\left(\mathrm{kg} \mathrm{ha}^{-1}\right)\end{array}$ & $\begin{array}{l}1000 \mathrm{SW} \\
(\mathrm{g})\end{array}$ & $\mathrm{HI}$ \\
\hline 1. $2006 \mathrm{MW} 6044$ & $29.0^{\mathrm{a}}$ & 46420 & $1560^{f-j}$ & $5195^{\mathrm{e}-\mathrm{i}}$ & $32.3^{\mathrm{d}-\mathrm{g}}$ & $29.8^{\mathrm{c}-\mathrm{h}}$ \\
\hline 2. ETSC 300003 & $23.4^{\mathrm{c}-\mathrm{g}}$ & 59753 & $2329^{\mathrm{b}-\mathrm{d}}$ & $7668^{b c}$ & $34.3^{\mathrm{c}-\mathrm{f}}$ & $30.3^{\mathrm{c}-\mathrm{g}}$ \\
\hline 3. $05 \mathrm{MW} 6019$ & $23.3^{\mathrm{c}-\mathrm{g}}$ & 38025 & $1287^{\mathrm{h}-\mathrm{j}}$ & $4244^{\mathrm{ij}}$ & $35.3^{\mathrm{b}-\mathrm{d}}$ & $30.3^{\mathrm{c}-\mathrm{g}}$ \\
\hline 4. $05 \mathrm{MW} 6073$ & $22.2^{\mathrm{e}-\mathrm{h}}$ & 44938 & $2397^{b c}$ & $6538^{\mathrm{b}-\mathrm{e}}$ & $37.7^{\mathrm{a}-\mathrm{c}}$ & $36.5^{\mathrm{ab}}$ \\
\hline 5. $2006 \mathrm{MW} 6185$ & $23.0^{\mathrm{d}-\mathrm{g}}$ & 58765 & $3283^{a}$ & $10457^{\mathrm{a}}$ & $35.0^{\mathrm{b}-\mathrm{e}}$ & $31.3^{\mathrm{b}-\mathrm{f}}$ \\
\hline 6. ETSC 300081 & $22.9^{\mathrm{d}-\mathrm{g}}$ & 51358 & $1968^{\mathrm{c}-\mathrm{f}}$ & $5708^{\mathrm{d}-\mathrm{i}}$ & $32.3^{\mathrm{d}-\mathrm{g}}$ & $34.8^{\mathrm{a}-\mathrm{c}}$ \\
\hline 7. ETSC 300086 & $22.4^{\mathrm{e}-\mathrm{h}}$ & 57778 & $1815^{\mathrm{e}-\mathrm{g}}$ & $5830^{\mathrm{d}-\mathrm{i}}$ & $37.7^{\mathrm{a}-\mathrm{c}}$ & $31.0^{\mathrm{b}-\mathrm{g}}$ \\
\hline 8. ETSC 300080 & $21.4^{\mathrm{f}-\mathrm{h}}$ & 54815 & $1818^{\mathrm{e}-\mathrm{g}}$ & $6267^{b-f}$ & $39.3^{\mathrm{a}}$ & $29.1^{\mathrm{c}-\mathrm{h}}$ \\
\hline 9. 2006 MW 6145 & $28.9^{\mathrm{ab}}$ & 39506 & $1771^{\mathrm{f}-\mathrm{h}}$ & $6039^{c-h}$ & $32.3^{\mathrm{d}-\mathrm{g}}$ & $30.2^{\mathrm{c}-\mathrm{g}}$ \\
\hline 10. ETSC 300087 & $23.4^{\mathrm{c}-\mathrm{g}}$ & 52346 & $1293^{\mathrm{h}-\mathrm{j}}$ & $3243^{\mathrm{j}}$ & $35.3^{\mathrm{b}-\mathrm{d}}$ & $40.5^{\mathrm{a}}$ \\
\hline 11. $2006 \mathrm{MW} 6112$ & $24.3^{\mathrm{c}-\mathrm{e}}$ & 47407 & $1992^{\mathrm{c}-\mathrm{f}}$ & $7034^{\mathrm{b}-\mathrm{d}}$ & $32.7^{\mathrm{d}-\mathrm{g}}$ & $28.0^{\mathrm{d}-\mathrm{h}}$ \\
\hline 12. 148 X FRAMIDA & $26.1^{\mathrm{bc}}$ & 49877 & $1607^{\mathrm{f}-\mathrm{i}}$ & $5150^{\mathrm{e}-\mathrm{i}}$ & $30.0^{\mathrm{g}}$ & $30.8^{\mathrm{b}-\mathrm{g}}$ \\
\hline 13. $05 \mathrm{MW} 6066$ & $24.3^{\mathrm{c}-\mathrm{e}}$ & 57284 & $1445^{\mathrm{g}-\mathrm{j}}$ & $6071^{\mathrm{b}-\mathrm{h}}$ & $35.3^{\mathrm{b}-\mathrm{d}}$ & $23.9^{\text {hi }}$ \\
\hline 14. $06 \mathrm{MW} 6015$ & $22.8^{\mathrm{e}-\mathrm{g}}$ & 47407 & $1310^{\mathrm{h}-\mathrm{j}}$ & $6394^{\mathrm{b}-\mathrm{f}}$ & $31.3^{\mathrm{e}-\mathrm{g}}$ & $20.7^{\mathrm{i}}$ \\
\hline 15. ETSC 300085 & $24.1^{\mathrm{c}-\mathrm{f}}$ & 48889 & $1841^{\mathrm{d}-\mathrm{g}}$ & $5853^{\mathrm{d}-\mathrm{i}}$ & $38.3^{\mathrm{ab}}$ & $32.0^{\mathrm{b}-\mathrm{f}}$ \\
\hline 16. $2006 \mathrm{MW} 6067$ & $23.9^{\mathrm{c}-\mathrm{f}}$ & 46914 & $1093^{j}$ & $4447^{h-j}$ & $38.7^{\mathrm{ab}}$ & $25.1^{\mathrm{g}-\mathrm{i}}$ \\
\hline 17. $05 \mathrm{MW} 6005$ & $20.9^{\mathrm{gh}}$ & 60741 & $2315^{\mathrm{b}-\mathrm{e}}$ & $6909^{b-d}$ & $36.7^{\mathrm{a}-\mathrm{c}}$ & $33.7^{\mathrm{b}-\mathrm{e}}$ \\
\hline 18. ETSC 300083 & $20.8^{\mathrm{gh}}$ & 59259 & $1638^{\mathrm{f}-\mathrm{i}}$ & $5473^{\mathrm{d}-\mathrm{i}}$ & $32.3^{\mathrm{d}-\mathrm{g}}$ & $30.5^{\mathrm{b}-\mathrm{g}}$ \\
\hline 19. ETSC 300082 & $21.4^{\mathrm{f}-\mathrm{h}}$ & 50370 & $1677^{\mathrm{f}-\mathrm{i}}$ & $6151^{\mathrm{b}-\mathrm{g}}$ & $35.0^{\mathrm{b}-\mathrm{e}}$ & $28.4^{\mathrm{d}-\mathrm{h}}$ \\
\hline 20. $05 \mathrm{MW} 6028$ & $23.1^{\mathrm{d}-\mathrm{g}}$ & 55803 & $1068^{j}$ & $4420^{\mathrm{h}-\mathrm{j}}$ & $35.0^{\mathrm{b}-\mathrm{e}}$ & $24.9^{\mathrm{g}-\mathrm{i}}$ \\
\hline 21. 2006 MW 6123 & $24.8^{\mathrm{c}-\mathrm{e}}$ & 36543 & $1826^{\mathrm{d}-\mathrm{g}}$ & $6736^{\mathrm{b}-\mathrm{e}}$ & $34.3^{\mathrm{c}-\mathrm{f}}$ & $27.7^{\mathrm{e}-\mathrm{h}}$ \\
\hline \multicolumn{7}{|l|}{ 22.Spv-245x1(146 x 354)-27 x } \\
\hline Framida-7-1 & $20.8^{\mathrm{gh}}$ & 58765 & $2535^{\mathrm{b}}$ & $7746^{\mathrm{b}}$ & $35.3^{\mathrm{b}-\mathrm{d}}$ & $32.8^{\mathrm{b}-\mathrm{e}}$ \\
\hline 23. SRN-39 & $20.8^{\mathrm{gh}}$ & 59753 & $2017^{\mathrm{c}-\mathrm{f}}$ & $5907 d-\mathrm{i}$ & $29.7^{g}$ & $34.1^{\mathrm{b}-\mathrm{d}}$ \\
\hline 24. Teshale & $19.7^{\mathrm{h}}$ & 49383 & $1660^{\mathrm{f}-\mathrm{i}}$ & $4740^{f-j}$ & $31.0^{\mathrm{fg}}$ & $35.2^{\mathrm{a}-\mathrm{c}}$ \\
\hline 25. Gobiye & $25.7^{\mathrm{cd}}$ & 44444 & $1190^{\mathrm{ij}}$ & $4516^{\mathrm{g}-\mathrm{j}}$ & $31.6^{\mathrm{d}-\mathrm{g}}$ & $26.5^{\mathrm{f}-\mathrm{i}}$ \\
\hline $\operatorname{LSD}(5 \%)$ & 2.83 & NS & 504.28 & 1687.41 & 3.79 & 6.20 \\
\hline $\mathrm{CV}(\%)$ & 7.4 & 21.3 & 17.2 & 17.3 & 6.7 & 12.5 \\
\hline
\end{tabular}

N.B. 'Means with the same letters are not significantly different from each other'; $\mathrm{PL}=$ Panicle length; $\mathrm{StC}=$ Stand count; $G Y=$ Grain yield; $A G B=$ Above ground biomass; $1000 \mathrm{SW}=1000$ seed weight; $\mathrm{HI}=\mathrm{Harvest}$ index

\section{Harvest Index}

Analysis of variance showed significant $(\mathrm{P} \leq 0.05)$ difference was observed among the genotypes tested. The Harvest Index (HI) values ranged from 20.7 to $40.5 \%$ in (Table 4). The highest value (40.5\%) was shown by

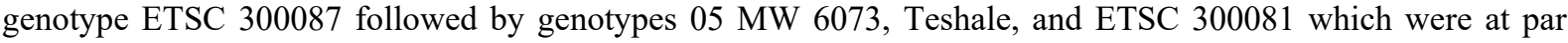
with the genotype of the highest HI. The lowest (20.7\%) harvest index was recorded from the genotype $06 \mathrm{MW}$ 6015. The genotypes $05 \mathrm{MW} 6066,05 \mathrm{MW} 6028,2006 \mathrm{MW} 6067$ and one of the resistant checks Gobiye were also recorded lower HI, which were at par with the least value recorded by the genotype $06 \mathrm{MW} 6015$. From this study the lowest HI values were observed from the genotypes of lower yield and the highest HI were also recorded from more of the genotypes achieved good yield. This implies the partitioning of the yield components to yield was better and were important for selection criteria of the genotypes.

\section{Striga count}

The mean number of Striga count was 24.7 per hectare which was the lowest number of Striga emergence in the area. This could be related to the seasonal variability for the Striga for preconditioning and germination (Logan and Stewart 1991). However, there was variability of Striga infestation among the genotypes tested in the area.

Analysis of variance showed that the number of Striga hermonthica at 50\% flowering and maturity of sorghum genotypes were highly significant $(\mathrm{P} \leq 0.01)$ (Table 5). The mean number of emerged Striga plant per plot at 50\% sorghum flowering ranged from zero (0) in ETSC 300003, ETSC 300080, 2006 MW 6145, ETSC 300082, 05 MW 6028, 2006 MW 6123, SRN-39, Gobiye to 2.07 in susceptible check (Teshale). Generally, 10 sorghum genotypes [were recorded lower Striga germination] and were not significantly different from the two resistant checks. The highest number of Striga was recorded on sorghum genotypes 2006 MW 6112 and 2006 MW 6067 (1.82plants per plot each), which was not significantly different from the susceptible check (Teshale) (2.07 plants per plot) (Table 5). Similarly, genotypes SPV-245 x 1(146 X 354)-27 x Framida-7-1 and ETSC 
300083 recorded the same values of 1.52 plants per plot, which was at par with the susceptible check (Teshale).

In present study the Striga count at maturity in various sorghum genotypes were also remained significant (Table 5). The mean Striga count per sorghum genotypes at maturity of the sorghum were varied between zero (0) to 1.28 per plot. Out of the 25 tested genotypes, 18 supported few number of Striga plants per plot and had similar reaction with the two resistant check varieties (Table 5). The variety $2006 \mathrm{MW} 6067$ had the highest Striga count (1.28 plot $\left.^{-1}\right)$ followed by genotypes 06 MW 6015 and ETSC 300083 with the value of 1.14 each. These genotypes were supporting more Striga plants than the susceptible check, and were significantly different from the check. Generally, sorghum genotypes 2006 MW 6044, ETSC 300003, 05 MW 6019, ETSC 300081, ETSC 300080, 2006 MW 6145, 05 MW 6005, ETSC 300082, 05 MW 6028 and 2006 MW 6123 did support either no or fewer Striga plants both at 50\% flowering and physiological maturity, which might suggest the level of resistance as it has been outlined in previous reports. Doggett (1988) and Ejeta et al. (1992) reported that crop genotypes which, when grown under conditions of Striga infestation, support significantly fewer Striga plants and have higher yields than the susceptible cultivars are considered as resistant to Striga.

Table 5: 1Mean values of Striga count at 50\% flowering and maturity per plot tested at Fadis during 2016 crop season

\begin{tabular}{|c|c|c|}
\hline \multirow[b]{2}{*}{ Genotype } & \multicolumn{2}{|c|}{ Traits } \\
\hline & SCF/plot & $\mathrm{SCH} /$ plot \\
\hline 2006 MW 6044 & $0.33(0.3) \mathrm{fg}$ & $0(0) \mathrm{d}$ \\
\hline ETSC 300003 & $0(0) \mathrm{g}$ & $0(0) d$ \\
\hline 05MW6019 & $0.33(0.3) \mathrm{fg}$ & $0(0) \mathrm{d}$ \\
\hline $05 \mathrm{MW} 6073$ & $0.8(1) \mathrm{d}-\mathrm{f}$ & $1(1) \mathrm{c}$ \\
\hline 2006 MW 6185 & $1.28(1.7) \mathrm{b}-\mathrm{d}$ & $0(0) \mathrm{d}$ \\
\hline ETSC 300081 & $0.33(0.3) \mathrm{fg}$ & $0(0) \mathrm{d}$ \\
\hline ETSC 300086 & $0.67(0.7) \mathrm{ef}$ & $0(0) d$ \\
\hline ETSC 300080 & $0(0) \mathrm{g}$ & $0(0) d$ \\
\hline 2006 MW 6145 & $0(0) \mathrm{g}$ & $0(0) \mathrm{d}$ \\
\hline ETSC 300087 & $1.28(1.7) b-d$ & $1(1) \mathrm{c}$ \\
\hline 2006 MW 6112 & $1.82(3.3) \mathrm{ab}$ & $1(1) c$ \\
\hline 148 X Framida & $1.28(1.7) b-d$ & $0(0) d$ \\
\hline 05 MW 6066 & $1.14(1.3) \mathrm{c}-\mathrm{e}$ & $0(0) \mathrm{d}$ \\
\hline 06 MW 6015 & $1.28(1.7) b-d$ & $1.14(1.33) b$ \\
\hline ETSC 300085 & $1.14(1.3) \mathrm{c}-\mathrm{e}$ & $0(0) \mathrm{d}$ \\
\hline 2006 MW 6067 & $1.82(3.3) \mathrm{ab}$ & $1.28(1.67) \mathrm{a}$ \\
\hline 05 MW 6005 & $0.33(0.3) \mathrm{fg}$ & $0(0) \mathrm{d}$ \\
\hline ETSC 300083 & $1.52(2.3) \mathrm{a}-\mathrm{c}$ & $1.14(1.33) b$ \\
\hline ETSC 300082 & $0(0) \mathrm{g}$ & $0(0) \mathrm{d}$ \\
\hline 05 MW 6028 & $0(0) \mathrm{g}$ & $0(0) \mathrm{d}$ \\
\hline 2006 MW 6123 & $0(0) \mathrm{g}$ & $0(0) \mathrm{d}$ \\
\hline SPV-245 X 1(146 X 354)-27 XFramida-7-1 & $1.52(2.3) \mathrm{a}-\mathrm{c}$ & $0(0) \mathrm{d}$ \\
\hline SRN-39 & $0(0) \mathrm{g}$ & $0(0) \mathrm{d}$ \\
\hline Teshale & $2.07(4.3) \mathrm{a}$ & $1(1) \mathrm{c}$ \\
\hline Gobiye & $0(0) \mathrm{g}$ & $0(0) \mathrm{d}$ \\
\hline Mean & 0.8 & 0.3 \\
\hline $\operatorname{LSD}(0.05)$ & 0.55 & 0.13 \\
\hline $\mathrm{CV} \%$ & 44.4 & 26.7 \\
\hline
\end{tabular}

Figures in the parenthesis are the original values; Numbers outside the parentheses are square roottransformed $\sqrt{\mathrm{x}+0.5}$; Means with the same letters are not significantly different from each other'; $\mathrm{SCF}=$ Striga Count at 50\% flowering; $\mathrm{SCH}=$ Striga count at physiological maturity.

\section{CONCLUSION}

Generally, even though the season was not conducive for maximum Striga emergence in the field, the significant variation were observed among the genotypes studied and it is suggested that the continuation of the experiments using the promising lines would confirm their resistance. Future research efforts should be directed towards understanding host resistance mechanisms and improvement of field screening at multiple hot spot areas. As the response mechanisms of Striga resistance in sorghum genotypes are distinct, post-attachment and marker assisted selection should be employed to observe the real resistant genotypes. 


\section{AKNOWLEDGMENT}

I would like to express my deep gratitude to my advisors Dr. Bulti Tesso, Haramaya University and Dr. Taye Tadesse, EIAR, Melkassa Agricultural Research Center (MARC) for their unreserved guidance, technical advice, suggestions and constructive criticisms and untiring help during my thesis research implementation. I am also grateful to Dr. Taye Tesema, Integrated Striga control project coordinator, for his support in providing every materials and chemicals needed for the bioassay laboratory part of this study. I also extend my sincere appreciation to Mr. Urgessa Tsega for his unreserved technical assistance

\section{References}

Aly R (2007). Conventional and biotechnological approaches for control of parasitic weeds. In Vitro Cellular Developmental Biology. 43:304-317.

Bouwmeester, H.J., Matusova, R., Zhongkui, S. and Beale, M.H. 2003. Secondary metabolites signalling in hostparasitic plant interactions. Current Opinion in Plant Biology 6: 358-364.

CSA (Central Statistical Agency). 2015. Agricultural sample survey 2014/2015: report on area and production of crops (private peasant holdings, main season), vol. 1. Addis Ababa: Federal Democratic Republic of Ethiopia, Central Statistical Agency.

CSA (Central Statistical Agency). 2016. Agricultural sample survey 2015/2016: report on area and production of crops (private peasant holdings, Meher season), vol. 1. Addis Ababa: Federal Democratic Republic of Ethiopia, Central Statistical Agency.

Ejeta G (2005). Integrating biotechnology, breeding, and agronomy in the control of the parasitic weed Striga spp in sorghum. Crop Science. P. 239-251.

Ejeta G (2007). Breeding Striga resistant in sorghum: Exploitation of intricate host-parasite biology. Crop Science. 47: 216-217.

Ejeta G, Babiker AGT, Butler L (2002). New approaches to the control of Striga. A training work shop on Striga resistance, Melkassa, Nazareth, Ethiopia, 14-17 May 2002.

Rebeka G. Hussein Sh., Laing M, Tongoona P. and Nigussie M (2014). A diagnostic appraisal of the sorghum farming system and breeding priorities in Striga infested agro-ecologies of Ethiopia. Agricultural Systems 123: 54-61.

Haussmann BIG, Hess DE., Reddy BV, Welz HG., and Geiger HH (2000). Analysis of resistance to Striga hermonthica in diallel crosses of sorghum. Euphytica 116:33-40.

Logan DC and Stewart GR (1991). Role of ethylene in the germination of the hemi-parasite Striga hermonthica. Plant Physiology, 97: 1435-1438.

Reddy BVS, Reddy PS, Sadananda AR, Dinakaran E, Kumar AA, Deshpande SP, Rao PS, Sharma HC, Sharma R, Krishnamurthy L and Patil JV (2012). Post rainy season sorghum: Constraints and breeding approaches. Journal of Agricultural Research 10.

Rich PJ, Grenier C, Ejeta G (2004). Striga resistance in wild sorghum. Crop Science. 44: 2221- 2229.

Hussien T (2006). Distribution of two Striga species and their relative impact on local and resistant sorghum cultivars in East Ethiopia. Tropical Science, 46(3): 147-150.

Tesfaye Tesso; Zenbaba Gutema; Aberra Deressa; Ejeta G, 2007. An integrated Strigamanagement option offers effective management of Striga in Ethiopia. In: Ejeta G., Gressel, J. (Eds.), Integrating New technologies for Striga Management Towards Ending the Witch hunt. World Scientific Publishing Co., USA, pp. 199212.

Legesse T (2016). Evaluation of Ethiopian Sorghum[Sorghum bicolor (L.) Moench] Landraces and Wild Relatives for Pre-Attachment Resistance Mechanisms to Striga[Striga hermonthica (Del.)]. MSc. thesis at Haramaya University, Haramaya.

Vasudeva RMJ (1985). Techniques for screening sorghums for resistance to Striga. ICRISAT Information Bulletin No. 20. International Crops Research Institute for the Semi-Arid Tropics (ICRISAT), Patancheru PO, Andhra Pradesh 502324, India. 